\title{
ARTIKELEN
}

\section{De keuze tussen strafrechtelijke en bestuursrechtelijke sanctionering en het criterium van de ernstige gedraging*}

\author{
Benny van der Vorm
}

\section{Inleiding}

In de nabije toekomst gaat het kabinet zich een oordeel vormen over de toe te passen criteria op grond waarvan de keuze tussen het bestuursrechtelijke en het strafrechtelijke sanctiestelsel dient te worden gemaakt. Wellicht wordt door het kabinet afscheid genomen van de 'open context' en 'besloten context', ${ }^{1}$ waarin vooral de effectiviteit van de handhaving centraal staat en minder aandacht wordt besteed aan de ernst van de gedraging. Volgens Roording is er geen delict ook moord, diefstal en verkrachting niet - dat rechtens niet via een administratief sanctiestelsel zou mogen worden afgedaan. ${ }^{2}$ De stelling van Roording is juist als dit administratieve sanctiestelsel voldoet aan de eisen die vanuit het perspectief van het Europees Verdrag voor de rechten van de mens (EVRM) worden gesteld aan een strafrechtelijke procedure. Het ligt echter niet voor de hand dat het bestuursrecht wordt ingezet om zware delicten, zoals moord en verkrachting, af te doen, omdat daders van dergelijke delicten - doorgaans - worden gestraft met een gevangenisstraf en dergelijke straffen afwezig zijn in het bestraffende bestuursrecht. Rogier heeft in zijn afscheidsrede aangegeven dat bij de keuze tussen bestuursrecht en strafrecht de ernst van de gedraging als keuzecriterium centraal zou moeten staan. ${ }^{3}$ Het gevolg hiervan is dat als sprake is van een ernstige gedraging, een strafrechtelijke afdoening op zijn plaats is. Als een a contrarioredenering wordt toegepast, is de consequentie dat bestuursrechtelijke sanctionering is aangewezen ten aanzien van minder ernstige gedragingen. Maar wat zijn minder ernstige gedragingen? Zijn dit de strafbare feiten die thans worden aange-

* Mr. dr. drs. Benny van der Vorm is universitair docent Straf(proces)recht aan de Universiteit Utrecht.

1 Kamerstukken I 2008/09, 31700 VI, D, p. 6-9.

2 Stelling bij J.F.L.R. Roording, Sanctierecht in de belastingen en de sociale zekerheid (diss. Nijmegen), Nijmegen: Ars Aequi Libri 1994.

3 L.J.J. Rogier, Bestuursrecht of strafrecht. Instrumentaliteit of moraliteit? (afscheidsrede Rotterdam), Den Haag: Boom Juridische uitgevers 2014, p. 14-15. In vergelijkbare zin: J. Crijns, 'Efficiëntie in het kwadraat. Over de lotgevallen van de kleine strafzaak na invoering van de strafbeschikking en het verlofstelsel', PROCES 2010, p. 392-405. 
merkt als overtredingen of kunnen dit ook bepaalde misdrijven zijn ${ }^{4}$ En wat betekent het ingeval het kabinet bepaalde strafbare feiten, zijnde minder ernstige gedragingen, zou overhevelen naar het bestuursrecht?

In deze bijdrage staat de volgende vraag centraal: 'Op welke wijze kan het criterium van de ernstige gedraging nader worden geoperationaliseerd?' Teneinde deze vraag te kunnen beantwoorden wordt ten eerste aandacht besteed aan de verhouding tussen het strafrecht en het bestuursrecht (paragraaf 2). Ten tweede wordt in het kort het pleidooi van Rogier besproken (paragraaf 3), waarna vervolgens het keuzecriterium van de ernstige gedraging nader wordt uitgewerkt (paragraaf 4). Er wordt besloten met een conclusie (paragraaf 5).

\section{De verhouding tussen het strafrecht en het bestuursrecht ${ }^{5}$}

\subsection{Inleiding}

Het bestuursrecht en het strafrecht behoren beide tot het publiekrecht. ${ }^{6}$ De Haan e.a. geven aan dat deze rechtsgebieden een aantal gemeenschappelijke uitgangspunten bezitten en dat de verhouding een kwestie is van afbakening en veel minder van een principieel verschil. ${ }^{7}$ Een belangrijke overeenkomst vinden zij in het legaliteitsbeginsel. Zowel in het bestuursrecht als in het strafrecht kunnen de overheidsorganen slechts beschikken over bevoegdheden voor zover hiervoor een wettelijke grondslag bestaat. ${ }^{8} \mathrm{Zij}$ zien echter ook een belangrijk verschil: het strafrecht is sanctierecht en dit geldt niet voor het bestuursrecht. Het strafrecht treedt in werking ten gevolge van een vermoedelijk gepleegde normovertreding en in die zin staat het strafrecht dan ook (mede) ten dienste van het bestuursrecht. ${ }^{9}$

Het bestuursrecht zelf bevat ook instrumenten in de zin van sancties, die kunnen worden toegepast indien bestuursrechtelijke regels (vermoedelijk) zijn geschonden. Volgens De Haan e.a. zijn dit in het bestuursrecht echter secundaire bevoegdheden. ${ }^{10}$ De primaire bevoegdheden in het bestuursrecht zijn volgens hen gelegen in de 'uitvoering en toepassing van de bestuursrechtelijke wetgeving'. ${ }^{11}$ Het toepassen van sancties in het bestuursrecht ziet volgens De Haan e.a. primair

4 In dit verband kan bijv. worden gewezen op art. $185 \mathrm{Sr}$. Overtreding van deze strafbepaling kan worden bestraft met een gevangenisstraf van ten hoogste twee weken of een geldboete van de tweede categorie.

5 Deze paragraaf is gebaseerd op B. van der Vorm, Ernstig gevaar. Een juridisch-empirisch onderzoek naar aard, doel en toepassing van de Wet Bibob (diss. Tilburg), Oisterwijk: Wolf Legal Publishers 2016, p. 140-146.

6 L. Rogier \& A. Hartmann, 'Verschillen en overeenkomsten tussen strafrecht en bestuursrecht', DD 1993, p. 1043.

7 P. de Haan, Th.G. Drupsteen \& R. Fernhout, Bestuursrecht in de sociale rechtstaat. Ontwikkeling, organisatie, instrumentarium, Deventer: Kluwer 2001, p. 57.

8 De Haan e.a. 2001, p. 58. Zij wijzen op de IRT-affaire als voorbeeld van de waarde van het (strafvorderlijk) legaliteitsbeginsel.

9 De Haan e.a. 2001, p. 58.

10 De Haan e.a. 2001, p. 59.

11 De Haan e.a. 2001, p. 59. 
De keuze tussen strafrechtelijke en bestuursrechtelijke sanctionering en het criterium van de ernstige gedraging

op de ordening van het maatschappelijk verkeer en niet op leedtoevoeging. ${ }^{12}$ De vraag kan worden gesteld in hoeverre deze constatering ook geldt ten aanzien van de bestuurlijke boete, aangezien aan deze sanctie een bestraffend, en dus een leedtoevoegend, karakter is toe te kennen. ${ }^{13}$ De Hullu meent dat de bestuursrechtelijke bestraffing een minder vergeldend karakter heeft dan strafrechtelijke bestraffing, maar dat de grenzen minder scherp zijn dan de verhouding tussen het strafrecht en het privaatrecht. ${ }^{14}$ Het beeld dat het bestuursrecht primair in aanmerking komt voor herstel en het strafrecht voor bestraffing, klopt volgens Michiels niet meer. Michiels wijst in dit verband op de bestuursdwang en dwangsom en de tot op een zekere hoogte vergelijkbare maatregelen en straffen in de Wet op de economische delicten (WED) en het Wetboek van Strafrecht. Zo wijst hij enerzijds op het bestraffende karakter van de bestuurlijke boete en op herstelmaatregelen in het strafrecht, zoals artikel 36f van het Wetboek van Strafrecht (Sr). Het strafrecht biedt ook tal van herstelmogelijkheden en hierdoor zijn de verschillen tussen het bestuursrecht en het strafrecht minder groot dan op het eerste gezicht wellicht lijkt. ${ }^{15}$

Het strafrecht speelt ook een rol bij de handhaving van het bestuursrecht. ${ }^{16}$ De Haan e.a. geven hiervan twee voorbeelden. Het strafrecht kan worden ingezet indien sprake is van een (vermoedelijke) overtreding van gedragingen in het commune strafrecht die nader zijn genormeerd in het bestuursrecht, zoals artikel 197 Sr. Blijkens de delictsomschrijving van deze strafbepaling is het strafbaar indien een vreemdeling in Nederland verblijft, terwijl hij weet of ernstige reden heeft te vermoeden dat hij op grond van een wettelijk voorschrift tot ongewenste vreemdeling is verklaard. In dit geval is sprake van strafrechtelijke handhaving van de Vreemdelingenwet 2000. Naast het commune strafrecht kan ook het bijzondere strafrecht wordt gehanteerd om bestuursrechtelijke normen te handhaven. Hierbij kan worden gewezen op de WED, die onder andere een rol vervult bij de handhaving van het milieubeleid, en in het bijzonder op de strafbare feiten die zijn neergelegd in de Wet milieubeheer. ${ }^{17}$ De Haan e.a. relativeren de strafrechtelijke invloed op de handhaving van bestuursrechtelijke wetten; zij zijn van mening dat hoewel het bestuursrecht zeker strafbepalingen omvat, deze lang niet altijd worden toegepast. ${ }^{18}$ Omgekeerd heeft Michiels aangegeven dat in het bestuursrecht de bestuursdwang en de dwangsom op de meeste gebieden de kern van de hand-

naar Nederlands recht, Deventer: Kluwer 2015, p. 32.

15 F.C.M.A. Michiels, Strafrechtelijke en bestuursrechtelijke handhaving: zoek de verschillen!', in: M. Groenhuijsen, T. Kooijmans \& J. Ouwerkerk (red.), Roosachtig strafrecht (Liber amicorum Theo de Roos), Deventer: Kluwer 2013, p. 454-455.

16 De Haan e.a. 2001, p. 59; Y. Buruma, De strafrechtelijke handhaving van bestuurswetten (diss. Leiden), Arnhem: Gouda Quint 1993.

17 Zie bijv. art. 10.60 Wet milieubeheer. Zie ook Buruma 1993.

18 P. de Haan, Th.G. Drupsteen \& R. Fernhout, Bestuurshandelingen, waarborgen, handhaving, Deventer: Kluwer 1998, p. 500. 
having uitmaken, terwijl de herstelmaatregelen in de WED nauwelijks worden toegepast. ${ }^{19}$

Over de verhouding van het bestuursrecht tot het strafrecht laten zich grofweg twee zienswijzen onderscheiden, waarbinnen tussenvormen mogelijk zijn. ${ }^{20}$ De eerste zienswijze kan het 'autonome' standpunt worden genoemd. Het strafrecht heeft in deze opvatting een zelfstandige plaats binnen het recht, en voorts 'wordt onder andere de nadruk gelegd op de eigen functie en theorie- en begripsvorming van het materiële strafrecht, de specificiteit van de strafprocedure en aan de bijzondere status die aan de taak en het handelen van verschillende procespartijen in het strafrecht wordt toegekend'. ${ }^{21}$ De tweede is een 'heteronome' zienswijze. Van daaruit 'wordt het strafrecht meer gezien als een accessoir deel van het recht waarbij het materiële recht, de procedure en de procesdeelnemers geen specifieke inhoud en status wordt toegekend'. ${ }^{22}$ Het strafrecht is met andere woorden een bijzondere vorm van bestuursrecht. ${ }^{23}$ In het navolgende zullen achtereenvolgens de volgende visies op het strafrecht worden besproken: de heteronome visie (het strafrecht als handhavingssysteem is niet bijzonder, althans niet meer bijzonder dan het bestuursrecht), de autonome visie (het strafrecht heeft specifieke kenmerken) en de gemengde visie (deze visie bevindt zich tussen de heteronome en de autonome visie).

\subsection{Het heteronome karakter van het strafrecht}

Knigge benadrukt vooral het heteronome karakter van het strafrecht. Hij geeft aan dat het historisch bepaalde onderscheid tussen het strafrecht en het bestuursrecht is achterhaald. ${ }^{24}$ Er was sprake van een verschil in ontwikkeling, in actoren en in doel. Op deze drie gebieden hebben zich echter belangrijke ontwikkelingen voorgedaan. ${ }^{25} \mathrm{Zo}$ is het strafrecht, mede onder invloed van het ordeningsstrafrecht, preventiever van aard geworden en geldt het omgekeerde voor het bestuursrecht. Dat is met de opkomst van de bestuurlijke boete punitiever geworden. ${ }^{26}$ Vanuit het oogpunt van rechtsbescherming merkt hij op dat in het strafrecht de zogenoemde procesverplichting ${ }^{27}$ geldt: uiteindelijk is de beslissing voorbehouden aan de strafrechter. ${ }^{28}$ Het bestuursrecht laat zich daarentegen kenmerken door een 'piepsysteem'. De beslissing is voorbehouden aan het bestuursorgaan, en de rechtsbescherming wordt gewaarborgd door het stelsel van bezwaar en beroep. ${ }^{29}$ Knigge geeft aan dat de rechtsbescherming in het strafrecht

19 Michiels 2013, p. 455.

20 Rogier \& Hartmann 1993, p. 1058.

21 Rogier \& Hartmann 1993, p. 1042.

22 Rogier \& Hartmann 1993, p. 1042.

23 G. Knigge 'De verkalking voorbij; over de verhouding van het strafrecht tot het bestuursrecht', RM Themis 2000, p. 83. Zie ook L.J.J. Rogier, Strafsancties, administratieve sancties en het una viabeginsel (diss. Rotterdam), Arnhem: Gouda Quint 1992, p. 17-18.

24 Ook Michiels kan tot deze stroming worden gerekend. Zie Michiels 2013, p. 454.

25 Knigge 2000, p. 85.

26 Knigge 2000, p. 86.

27 Zie ook J.F. Nijboer, De taken van strafrechter, Deventer: Gouda Quint 2000, p. 29.

28 Knigge 2000, p. 86.

29 Knigge 2000, p. 86. 
soms ook wordt geboden door middel van een 'piepsysteem'. ${ }^{30} \mathrm{Hij}$ wijst in dit verband onder andere op de beklagprocedure van artikel 12 van het Wetboek van Strafvordering (Sv) en de beklagprocedure met betrekking tot de executie van de vrijheidsstraf, die is neergelegd in artikel 13 lid $4 \mathrm{Sr}$ en artikelen 60 e.v. Penitentiaire beginselenwet. ${ }^{31}$ Voorbeelden van de procesverplichting in het bestuursrecht is Knigge niet tegengekomen. ${ }^{32}$

Knigge stelt dat er geen principieel bezwaar is om wat gemeenschappelijk is, ook gemeenschappelijk te regelen. Voorts is een algemene strafrechtelijke en bestuursrechtelijke overkoepelende theorie noodzakelijk om te kunnen beoordelen in hoeverre de 'toepassing van algemene regels een inhoudelijk bevredigend resultaat oplevert'. ${ }^{33}$ Hij stelt in dit geval het volgende:

'Die theorie zou bijvoorbeeld antwoord moeten kunnen geven op de vraag welke vorm van rechtsbescherming (een piepsysteem of een procesverplichting) in een bepaald geval het meest aangewezen is. Een belangrijk criterium lijkt de ingrijpendheid van het overheidsoptreden te zijn. ${ }^{34}$

Een dergelijke overkoepelende theorie zou volgens Knigge antwoord moeten geven op vragen zoals welke sancties door de rechter kunnen worden opgelegd en welke sancties aan bestuursorganen kunnen worden toevertrouwd, en of er een verschil in waarborgen tussen punitieve en niet-punitieve sanctionering dient te bestaan. ${ }^{35}$ Wanneer Knigge zichzelf de vraag stelt in hoeverre de Algemene wet bestuursrecht $(\mathrm{Awb})$ van toepassing kan worden verklaard op het gebied van strafvordering, komt hij tot de conclusie dat regels van bestuursrecht inderdaad kunnen worden toegepast op dit terrein. ${ }^{36}$ Zo ziet hij geen problemen om de algemene beginselen van behoorlijk bestuur toe te passen op de strafrechtelijke handhaving. ${ }^{37}$ Ook doet hij het voorstel om de oplegging van boetes door bestuursorganen te regelen in het Wetboek van Strafvordering. Op deze wijze worden alle punitieve sancties geregeld in één regelsysteem. Hij gaat nog een stapje verder door te stellen of het wellicht niet mogelijk zou zijn om in het verband van het ordeningsrecht alle sancties in het kader van wetshandhaving op te kunnen leggen. Hier vallen dan ook bestuursdwang en de punitieve intrekking van vergunningen onder. ${ }^{38}$

Zijn eindconclusie is dat zowel het strafrecht als het bestuursrecht een bestaansrecht als afzonderlijke academische discipline hebben, maar dat ze wel voor een

Ook de OM-afdoening kan worden beschouwd als een 'piepsysteem'.

Knigge 2000, p. 87.

Knigge 2000, p. 87.

Knigge 2000, p. 88.

Knigge 2000, p. 88.

Knigge 2000, p. 88.

Knigge 2000, p. 96.

Knigge 2000, p. 90. Zie ook O.J.D.M.L. Jansen, Het handhavingsonderzoek (diss. UvA), Nijmegen: Ars Aequi Libri 1999.

Knigge 2000, p. 96. 
deel samenvallen. De verhouding tussen beide rechtsgebieden dient daarom opnieuw te worden vastgesteld. ${ }^{39}$

\subsection{Het autonome karakter van het strafrecht}

Deze heteronome visie van Knigge is bekritiseerd door 't Hart. ${ }^{40}$ Laatstgenoemde geeft aan dat Knigge 'autonomie eerst impliciet in de toenemende mate karakteriseert als autarkie, vervolgens bestrijdt dat het strafrecht autark zou zijn en ten slotte concludeert dat het dús niet autonoom is'. ${ }^{41}$ In de opvatting van 't Hart staat het strafrecht niet los van andere rechtsgebieden, maar heeft het wel eigen specifieke kenmerken. Dit noemt hij 'autonomie'. ${ }^{42}$ Wanneer hij kijkt naar overeenkomsten tussen het strafrecht en het bestuursrecht, duidt hij op de algemene beginselen van behoorlijk bestuur. In tegenstelling tot Knigge is 't Hart van mening dat de bestuursrechtelijke uitwerking van deze beginselen niet onverkort kan worden toegepast op het strafprocesrecht. ${ }^{43}$

't Hart is het met Knigge eens dat een noodzaak tot herbezinning bestaat door de opkomst van het bestuurlijk strafrecht, maar hij is van mening dat aan een dergelijke feitelijkheid niet zomaar een normatieve kracht mag worden toegekend. ${ }^{44}$ Hij geeft hierover het volgende aan:

'Inderdaad worden sommige begrippen binnen het ene rechtsgebied opgevuld volgens de betekenisinhoud die zij hebben binnen een ander rechtsgebied of zelfs binnen een geheel andere discipline. Maar naast verbanden en overlappingen kunnen zich (...) ook verschillen voordoen. Indien de gerechtvaardigdheid - zo niet noodzaak - van vormen van eigenheid niet meer duidelijk onder ogen wordt gezien, ontstaat een probleem. Want dat raakt de grondslagen van het rechtsstatelijk bestel, waarin het strafrecht een bijzondere vorm is van een samengaan van ordening en daaraan inherente individuele rechtsbescherming.' 45

De notie van het autonome karakter van het strafrecht hoeft volgens 't Hart zeker geen voortdurende noodzaak te betekenen om bij afbakening de bestaande toestand te bevestigen. Een zorgvuldige en grondige onderbouwing is in dit verband noodzakelijk. ${ }^{46}$

40 A.C. 't Hart, 'De auton

41 't Hart 2001, p. 245.

42 't Hart 2001, p. 245. Zie ook H.A. Demeersseman, De autonomie van materiële strafrecht, Arnhem: Gouda Quint 1985.

43 't Hart 2001, p. 246. Zie ook C.P.M. Cleiren, Beginselen van een goede procesorde. Een analyse van rechtspraak in strafzaken (diss. Leiden), Arnhem: Gouda Quint 1989 en C.P.M. Cleiren, 'Identiteit van beginselen van behoorlijke strafrechtspleging en beginselen van behoorlijk bestuur?', $D D$ 1990, p. 497-514.

44 't Hart 2001, p. 248.

45 't Hart 2001, p. 248.

46 't Hart 2001, p. 249. 
De keuze tussen strafrechtelijke en bestuursrechtelijke sanctionering en het criterium van de ernstige gedraging

\subsection{Het gemengde karakter van het strafrecht}

Het eigen karakter van het strafrecht is volgens De Hullu gelegen in 'de sanctie die aan overtreding van de delictsomschrijving kan worden verbonden, de doeleinden van sanctionering en de manier waarop en de organen waardoor die sanctie kan worden vastgesteld'. ${ }^{47}$ Het vergeldende karakter van bestuursrechtelijke bestraffing is volgens De Hullu minder sterk aanwezig, maar hij geeft wel aan dat de begrenzing tussen deze vorm van het bestuursrecht en het strafrecht minder scherp te maken is dan de verhouding tussen het strafrecht en het privaatrecht. ${ }^{48}$ Het strafrecht, of meer specifiek gesteld de strafrechtelijke aansprakelijkheid, heeft in zijn visie een eigen, maar geen scherp omlijnd karakter. Hij neemt dus een minder sterk standpunt in dan 't Hart.

Onder verwijzing naar een overzicht van de toenmalige minister van Justitie Donner geeft hij een overzicht waarin uitgangspunten zijn geformuleerd over de keuze tussen verschillende sanctiestelsels. ${ }^{49}$ Het betreffen hier volgens De Hullu echter graduele verschillen, zodat niet onverkort hoeft te worden gekozen tussen het autonome of het heteronome karakter van het strafrecht. ${ }^{50}$ Op deze wijze 'kan de vraag onder ogen worden gezien waarom het Algemeen Deel van het Wetboek van Strafrecht niet van toepassing zou kunnen worden verklaard op de regels voor bestuursrechtelijke aansprakelijkheidsstelling en sanctionering, maar ook of bepaalde bestuursrechtelijke regels voor het materiële strafrecht inspirerend zouden kunnen zijn'. ${ }^{51}$

De Hullu geeft aan dat het onderscheid tussen het strafrecht en het bestuursrecht betrekkelijk is en daarom goed kan worden gewerkt met het formele criterium. Dit criterium houdt de kwalificatiekeuze van de wetgever in. De wetgever bepaalt of sprake is van een strafbaar feit of van een feit waarop een bestuurlijke boete is gesteld. Er is volgens De Hullu sprake van een strafbaar feit indien de wetgever een feit daadwerkelijk als strafbaar feit heeft gekwalificeerd. Of in de woorden van De Hullu:

'Strafbare feiten zijn die overtredingen van rechtsregels die blijkens de keuze van de wetgever als strafbare feiten zijn benoemd en ter zake waarvan door instanties uit het strafrecht strafrechtelijke sancties kunnen worden opgelegd wanneer aan de voorwaarden voor de strafrechtelijke aansprakelijkheid is voldaan. Dit criterium is alledaags en klassiek, ook al wordt erkend dat er geen sprake is van eenduidig en tijdloos afgebakende, maar meer van in elkaar overlopende en elkaar gedeeltelijk overlappende rechtsgebieden.' 52

Dit formele criterium levert geen belemmeringen op in het licht van het autonome begrip 'a determination of a criminal charge', zoals deze is neergelegd in 
artikel 6 lid 2 EVRM, ${ }^{53}$ aangezien de nationale kwalificatie van het zijn van een strafbaar feit niet doorslaggevend is. Indien een sanctie bestraffend en preventief is bedoeld, is de kans groot dat deze sanctie als een 'criminal charge' wordt aangemerkt, met als gevolg dat de betrokkene de rechten uit de leden 2 en 3 van artikel 6 EVRM toekomen. ${ }^{54}$ De bestuursrechter dient het opleggen van een bestuurlijke boete, die kan worden beschouwd als een 'criminal charge', indringend te toetsen op de evenredigheid, en een doorgaans terughoudende opstelling van de bestuursrechter volstaat niet.

\section{De opvatting van Rogier 55}

In het voorgaande zijn de verschillende visies op het strafrecht en de verhouding tot het bestuursrecht besproken. Het is echter nog niet duidelijk onder welke voorwaarden strafrechtelijke of bestuursrechtelijke sanctionering is geïndiceerd. In zijn afscheidsrede heeft Rogier gepleit voor de toepassing van het criterium van de 'ernstige gedraging'. Ten aanzien van de keuze tussen strafrecht en bestuursrecht speelt doelmatigheid in de opvatting van Rogier geen prominente rol. Hij geeft in zijn afscheidsrede aan dat de wetgever zich bij de keuze tussen bestuursrecht of strafrecht vooral laat leiden door een instrumentele visie. Hiermee bedoelt Rogier dat het recht wordt opgevat als een middel dat de overheid ten dienste staat om zo doeltreffend en zo doelmatig mogelijk ongewenst gedrag te bestrijden. ${ }^{56}$ Rogier vraagt meer aandacht voor de ernst van de gedraging als keuzecriterium. ${ }^{57}$ Dit vangt hij onder de term 'moraliteit', waarmee hij bedoelt dat over het ongewenste gedrag een ethisch waardeoordeel wordt geveld. ${ }^{58}$ Aan de hand van drie handhavingsterreinen - prostitutie, drugs en wegverkeer - concludeert Rogier dat indien sprake is van ernstige gedragingen, het primaat ligt bij de strafrechtelijke handhaving en niet bij het bestuursrecht. Weliswaar kan het bestuur in preventieve zin een belangrijke bijdrage leveren aan de bestrijding van onrecht, maar justitie zou bij ernstige gedragingen 'meer zijn tanden moeten laten zien' en het optreden niet moeten overlaten aan het bestuur. Zo zou het intrekken van vergunningen in de prostitutiesector - indien sprake is van ernstige gedragingen - geheel en uitsluitend bij justitie en de strafrechter dienen te

53 Dit begrip wordt ruim geïnterpreteerd, zie bijv. EHRM 21 februari 1984, NJ 1988/937 (Öztürk/ Duitsland) en EHRM 24 februari 1994, NJ 1994/496, m.nt. Alkema (Bendenoun/Frankrijk).

54 De Hullu 2015, p. 35.

55 Deze paragraaf is gebaseerd op Van der Vorm 2016, p. 152-153.

56 Rogier 2014, p. 15.

57 Met betrekking tot de keuze tussen het bestuursrechtelijke en het strafrechtelijke sanctiestelsel is het criterium van de 'ernstige gedraging' niet de enige optie. Volgens sommige auteurs is het doelmatigheidscriterium doorslaggevend. Zie F.C.M.A. Michiels, Wegen in het handhavingsrecht, presentatie tijdens het symposium 'Handhaven in de grote stad' ter ere van het emeritaat van Lodewijk Rogier. In de onderhavige bijdrage speelt het toepasselijke criterium een ondergeschikte rol, aangezien het gaat om de vraag in hoeverre de bestuursrechtelijke vrijheidsstraf dient te worden ontwikkeld indien het kabinet zou besluiten om bepaalde strafrechtelijke delicten over te hevelen naar het bestuursrecht. 
De keuze tussen strafrechtelijke en bestuursrechtelijke sanctionering en het criterium van de ernstige gedraging

liggen. ${ }^{59}$ Hoewel Rogier in zijn afscheidsrede duidelijk betoogt waarom het criterium van de ernstige gedraging leidend zou moeten zijn, maakt hij niet duidelijk wanneer nu precies sprake is van een ernstige gedraging. In het navolgende wordt het criterium van de ernstige gedraging nader geoperationaliseerd.

\section{De keuze tussen het strafrecht en het bestuursrecht}

\subsection{Inleiding}

De keuze tussen bestuursrechtelijke en strafrechtelijke sanctionering is een onderwerp dat al geruime tijd speelt. Het is vooral de opkomst van de bestuurlijke boete, maar ook de toepassing van de strafbeschikking, die duidelijkheid vraagt omtrent de keuze tussen bestuursrecht en strafrecht. ${ }^{60}$ De wetgever heeft verschillende indicatoren ontwikkeld aan de hand waarvan kan worden beoordeeld in hoeverre bestuursrechtelijk of strafrechtelijk optreden is geïndiceerd. Met betrekking tot de oplegging van de bestuurlijke boete is door de wetgever aangegeven dat deze uitsluitend kan worden opgelegd ten aanzien van de overtreding van regels met een geringe normatieve lading, hetgeen betekent 'dat de overtreding van de norm in de regel geen letsel aan personen of omvangrijke schade aan goederen veroorzaakt'. ${ }^{61}$ Voorts dient de norm duidelijk genoeg te zijn omschreven, zodat een vaste gedragslijn kan worden ontwikkeld die een eenvoudige en efficiënte uitvoering waarborgt. ${ }^{62}$ Daarnaast zijn indicaties gecreëerd met betrekking tot de handhavingspraktijk en het handhavingsbeleid. ${ }^{63}$

In verband met de inwerkingtreding van de Wet OM-afdoening stond het vraagstuk 'bestuursrecht of strafrecht' prominent op de agenda. In algemene zin verdient volgens de wetgever strafrechtelijke handhaving de voorkeur boven bestuursrechtelijke handhaving als de aard van het feit, de ernst van de rechtsschending, de samenhang met andere feiten of de behoefte aan toepassing van dwangmiddelen daartoe aanleiding geeft. Bestuursrechtelijke handhaving is aangewezen indien sprake is van eenvoudig vast te stellen rechtsschendingen, geen zware straffen nodig zijn en geen behoefte is aan dwangmiddelen. ${ }^{64}$ Thans wordt bestuursrechtelijke handhaving aanbevolen als sprake is van een 'besloten context' (gespecialiseerd bestuursorgaan, afgebakende doelgroep en verbindingen tussen die twee in verband met de uitvoering van de wet ${ }^{65}$ ), en strafrechtelijk optreden ligt meer in de rede ten aanzien van de 'open context' (geen rechtsbetrekking tussen burger en overheid, regelgeving heeft betrekking op eenieder ${ }^{66}$ ). Het onderscheid tussen de 'besloten context' en 'open context' is bekritiseerd,

60 Michiels 2013, p. 460-461; M.S. Groenhuijsen \& T. Kooijmans, 'Probleemoplossing door voortschrijdende wetgeving in het strafrecht?', DD 2010, p. 445-447.

61 Kamerstukken II 1999/2000, 26800 VI, 67, p. 11.

62 Kamerstukken II 1999/2000, 26800 VI, 67, p. 11.

63 Kamerstukken II 1999/2000, 26800 VI, 67, p. 11.

64 Kamerstukken II 2005/06, 29849, 30, p. 4.

65 Kamerstukken I 2008/09, 31700 VI, D, p. 6.

66 Kamerstukken I 2008/09, 31700 VI, D, p. 6-7. 
omdat sprake zou zijn van een gebrek aan onderscheidend vermogen. ${ }^{67}$ In dit verband dient evenwel voor ogen te worden gehouden dat het kabinet heeft onderkend dat het verschil tussen strafrechtelijke en bestuursrechtelijke 'delicten' vooral wordt bepaald door de ernst van het delict en de aard van de daaraan verbonden sancties. ${ }^{68}$ Officieel is het standpunt van het kabinet echter nog immer gelegen in het onderscheid tussen de 'open context' en de 'besloten context'.

Op 13 juli 2015 heeft de Afdeling advisering van de Raad van State een ongevraagd advies uitgebracht aan de minister van Veiligheid en Justitie, waarin zij haar eigen visie geeft over de keuze tussen sanctiestelsels. ${ }^{69}$ Volgens de afdeling geldt het criterium van 'open en besloten' context slechts als vertrekpunt en laat het alle ruimte voor een andere keuze dan die uit het onderscheid tussen de 'open en besloten context' zou moeten volgen. Vervolgens concentreert de afdeling zich op het verschil in rechtsbescherming tussen het bestuursrecht en strafrecht en beveelt zij aan deze beter op elkaar af te stemmen, waarmee wordt bedoeld dat de rechtsbescherming in het bestuursrecht zo veel mogelijk moet worden opgekrikt tot het niveau van het strafrecht.

$\mathrm{Na}$ het verschijnen van het advies van de Raad van State is een interdepartementale ambtelijke werkgroep ingericht die tot taak heeft een nader rapport te schrijven als reactie op het advies van de afdeling, en daarmee een nieuw kabinetsstandpunt over de keuze tussen sanctiestelsels voor te bereiden. Deze werkgroep heeft haar conclusies al getrokken, maar het kabinet heeft besloten het innemen van een standpunt over te laten aan een nieuw kabinet. Er bestaat dus een reële mogelijkheid dat het kabinet afscheid gaat nemen van de 'besloten context' en 'open context' als de toepasselijke criteria. Wat kunnen de gevolgen zijn, ingeval het criterium van de ernstige gedraging leidend wordt in de keuze tussen het bestuursrecht en het strafrecht? De vraag die hieraan voorafgaat, is wat nu precies onder ernstige gedragingen dient te worden verstaan.

\subsection{De operationalisering van de (minder) ernstige gedraging}

Het criterium van de ernstige gedraging kan worden gevonden in het onderscheid tussen misdrijven en overtredingen. De Hullu heeft aangegeven dat ernstiger strafbare feiten, vooral waarbij een vrijheidsstraf in beeld komt, als misdrijven worden aangemerkt. Is sprake van een minder ernstig feit, waarbij vooral een geringe vermogensstraf de meest passende reactie is, dan wordt dat aangemerkt als overtreding. ${ }^{70}$ Hierbij dient evenwel te worden opgemerkt dat ook veel overtredingen worden bedreigd met een vrijheidsstraf, namelijk de hechtenis. Deze tweedeling van strafbare feiten is - bezien vanuit een historische context - niet altijd vanzelfsprekend geweest. Simmelink heeft aangegeven dat 'de discussie over de indeling van strafbare feiten en de vraag of naast het strafrecht ruimte moet bestaan voor de administratie om ter zake van lichte overtredingen zelf-

67 Zie bijv. A.R. Hartmann, Over de grenzen van de dogmatiek en into fuzzy law (oratie Rotterdam), Maklu: Apeldoorn/Antwerpen 2011, p. 39 e.v. Zie ook Michiels 2013, p. 461.

68 De Hullu 2015, p. 34.

69 Advies van de Afdeling advisering van de Raad van State aan de minister van Veiligheid en Justitie inzake sanctiestelsels, Stcrt. 2015, nr. 30280. 
standig sancties op te leggen, al oud is' ${ }^{71}$ Hij geeft aan dat het inhoudelijke onderscheid tussen de categorisering van delicten steeds te herleiden is tot rechtsdelicten en wetsdelicten. ${ }^{72}$ Rechtsdelicten betreffen misdrijven en wetsdelicten overtredingen. Meer specifiek ten aanzien van rechtsdelicten: de strafwet verbindt straf aan de schending van een rechtsnorm die 'reeds als zodanig in de samenleving van kracht is en wellicht op andere rechtsterreinen ook handhaving vindt'. ${ }^{73}$ Het ontwikkelen van wetsdelicten houdt in het strafbaar stellen van de schending van onbekende normen. Het onderscheid tussen rechtsdelicten en wetsdelicten valt min of meer samen met het onderscheid tussen misdrijven en overtredingen, waarbij de minst zware overtredingen vaak een bestuursrechtelijke ondergrond hebben. ${ }^{74}$ Van oudsher strekt het strafrecht zich uit tot misdrijven, maar dit geldt niet ten aanzien van overtredingen. Zo was het in het begin van de negentiende eeuw gebruikelijk dat de oplegging van sancties ten aanzien van overtredingen (van 'policie') door het bestuur geschiedde. Dit bestuur kon ten aanzien van 'policieovertredingen' ook vrijheidsstraffen van maximaal enkele dagen opleggen. ${ }^{75}$ Gaandeweg verdween het onderscheid tussen de strafrechtelijke misdrijven en de bestuursrechtelijke 'policieovertredingen'. Simmelink laat op grond van een historische analyse zien dat 'het onderscheid tussen misdrijven en overtredingen en tussen strafbare feiten en administratief beboetbare feiten slechts relatief van aard is'. ${ }^{76}$

Het onderscheid tussen misdrijven en overtredingen dient te worden gerelativeerd, omdat het uitsluitend aanmerken van strafrechtelijke overtredingen als minder ernstige gedragingen problematisch is. Bij wijze van voorbeeld kan worden gewezen op het misdrijf van artikel 185 Sr. Blijkens deze strafbepaling kan 'hij die bij een terechtzitting of ter plaatse waar een ambtenaar in het openbaar in de rechtmatige uitoefening van zijn bediening werkzaam is, opschudding veroorzaakt en na het door of vanwege het bevoegd gezag gegeven bevel zich niet verwijdert', worden gestraft met een gevangenisstraf van ten hoogste twee weken of een geldboete van de tweede categorie. De plaatsing van dit delict in de categorie 'misdrijven' doet in abstracto vermoeden dat het een zwaarder delict is dan de 'overtredingen'. In concreto kan een ander beeld ontstaan. Zo kan overtreding van artikel $450 \mathrm{Sr}$ - het nalaten van hulpverlening aan een in levensgevaar verkerend persoon - worden bestraft met een hechtenis van ten hoogste drie maanden. Dit voorbeeld illustreert dat overtredingen met een hogere vrijheidsstraf kunnen

71 J.B.H.M. Simmelink, 'Over misdrijven, overtredingen en administratieve gedragingen', in: M.S. Groenhuijsen \& J.B.H.M. Simmelink (red.), Glijdende schalen (Liber amicorum J. de Hullu), Nijmegen: Wolf Legal Publishers 2003, p. 512.

72 Simmelink 2003, p. 512-513. In dit verband kan ook worden gewezen op het Duitse verschil tussen Verfassungsstrafrecht (er is sprake van justitieel onrecht, waarbij de normen voortvloeien uit de ethische overtuigingen van de gemeenschap) en Verwaltungsstrafrecht (er is sprake van bestuurlijk onrecht, waarbij de normen voortkomen uit de staatswil). Zie D. Van Daele, Het openbaar ministerie en de afhandeling van strafzaken in Duitsland. Samenleving Criminaliteit \& Strafrechtspleging deel 21b, Leuven: Universitaire Pers 2000, p. 294.

73 C. Kelk \& F. de Jong, Studieboek materieel strafrecht, Deventer: Wolters Kluwer 2016, p. 14.

74 Kelk \& De Jong 2016, p. 14-15.

75 Simmelink 2003, p. 513-515.

76 Simmelink 2003, p. 529. 
worden bedreigd dan misdrijven. Het gevolg hiervan is dat zowel overtredingen als misdrijven kunnen worden aangemerkt als minder ernstige gedragingen. De hoogte van de vrijheidsstraf kan een indicatie van de ernst van het feit zijn. ${ }^{77}$ Dit geldt eveneens voor het ontbreken van een vrijheidsstraf in de sanctienorm. Uit artikel $448 \mathrm{Sr}$ - zijnde een overtreding - blijkt namelijk dat 'hij die niet voldoet aan een wettelijke verplichting tot aangifte aan de ambtenaar van de burgerlijke stand voor de registers van geboorte of overlijden, wordt gestraft met geldboete van de eerste categorie'. De afwezigheid van de mogelijkheid om een vrijheidsstraf op leggen is een indicatie dat hier sprake is van een minder ernstige gedraging, maar ook deze vlieger gaat niet altijd op. Volgens artikel 1:81 van de Wet op het financieel toezicht kunnen bestuurlijke boetes van miljoenen euro's worden opgelegd. Bezwaarlijk kan worden volgehouden dat het bestuursrechtelijke delict ten aanzien waarvan hoge bestuurlijke boetes kunnen worden opgelegd, niet zijn aan te merken als een ernstige gedraging. Ook in het bestraffende bestuursrecht kan dus sprake zijn van ernstige gedragingen.

Het voorgaande laat zien het onderscheid tussen ernstige en mindere ernstige gedragingen bepaald geen sinecure is, en het onderscheid tussen overtredingen en misdrijven onvoldoende aanknopingspunten biedt. Eerder heb ik daarom een lans gebroken voor de toepasbaarheid van de strafbeschikking als onderscheidend criterium. ${ }^{78}$ De operationalisering van de ernstige gedraging zou kunnen zijn gelegen in de delicten waarvoor een strafbeschikking niet kan worden uitgevaardigd. Het delict is dan immers te zwaar om af te doen door middel van een strafbeschikking en buiten het gezichtsveld van de strafrechter te houden. Zo geeft Sillen terecht aan dat de strafbeschikking alleen geschikt is om minder ernstige delicten af te doen die onder het bereik van de Wet OM-afdoening vallen. ${ }^{79}$ Naar mijn mening is sprake van een minder ernstige gedraging indien het mogelijk is om ten aanzien van de desbetreffende gedraging een strafbeschikking uit te kunnen vaardigen. ${ }^{80}$ Zo beschouwd kunnen zowel overtredingen als misdrijven worden aangemerkt als minder ernstige gedragingen.

\subsection{De afdoening van bestuursrechtelijke 'delicten' als minder ernstige gedragingen}

Het zijn niet zozeer de afstemmingsregels die Rogier nopen tot het pleiten voor het ernstige gedraging-criterium ten aanzien van de keuze tussen sanctiestelsels. Hij wil een tegenwicht bieden aan de vooral instrumentalistische visie van de wetgever. Ten aanzien van de keuze tussen bestuursrecht en strafrecht laat de wetge-

77 Voor de wetgever van 1886 was het verschil tussen de gevangenisstraf en de hechtenis bijzonder groot.

78 Een andere operationalisering van de 'ernstige gedraging' is gegeven door Sillen. Er is sprake van een ernstige gedraging als de overtreder een ernstig moreel verwijt wordt gemaakt. Hier is sprake van wanneer de gedraging is gericht tegen de onaantastbaarheid van het lichaam en een bepaalde onomkeerbare straf kan worden opgelegd ('een straf van vrijheidsontneming, een taakstraf en andere naar hun aard onomkeerbare straffen'). Voldoet de gedraging aan beide voorwaarden, dan dient de gedraging niet door het bestuur te kunnen worden afgedaan. Zie J.J.J. Sillen, 'Straffend bestuur, de rechter en de Grondwet', RM Themis 2014, p. 36-37.

79 Sillen 2014, p. 28.

80 De verantwoording van deze operationalisering kan worden gevonden in Van der Vorm 2016, p. 156 e.v. 
ver zich vooral leiden door het doelmatigheidscriterium. De (veronderstelde) effectiviteit is leidend. ${ }^{81}$ Bezien in dit licht is het aanbevelingswaardig dat Rogier een tegengeluid laat horen, maar aan de toepassing van het criterium van de ernstige gedraging kleeft wel een bezwaar. Toepassing van dit criterium kan ertoe leiden dat de greep van het bestuursrecht op minder ernstige feiten groter wordt dan thans het geval is, waarbij direct de kanttekening dient te worden gemaakt dat de bestuurlijke boete ook wordt toegepast ten aanzien van complexe en ernstige vergrijpen. ${ }^{82}$

Hoe dient te worden gereageerd op minder ernstige gedragingen? Deze minder ernstige delicten zouden kunnen worden overgeheveld naar het bestuursrecht, zoals ook is gebeurd met betrekking tot lichte verkeersovertredingen. ${ }^{83}$ Theoretisch gezien bestaat de mogelijkheid dat de bestuursrechter vrijheidsstraffen kan opleggen ten aanzien van bestuursrechtelijke delicten. De wetgever heeft tot op heden geen acht geslagen op deze bestuursrechtelijke vrijheidsstraf, aangezien hij heeft aangegeven dat als nieuwe bestraffende sancties zijn gewenst, een strafrechtelijke regeling het primaat heeft. ${ }^{84}$ Ook heeft de wetgever aangegeven dat wanneer het wenselijk is om de overtreding van de norm te bedreigen met een vrijheidsbenemende of vrijheidsbeperkende straf of maatregel, slechts het strafrecht in aanmerking komt. ${ }^{85}$

\section{Conclusie}

In de nabije toekomst gaat het kabinet zich een oordeel vormen over de criteria op grond waarvan de keuze tussen het bestuursrechtelijke en het strafrechtelijke sanctiestelsel dient te worden gemaakt, hetgeen kan betekenen dat afscheid wordt genomen van de sterk bekritiseerde 'open context' en 'besloten context'. In zijn afscheidsrede heeft Rogier ervoor gepleit om bij de keuze tussen bestuursrecht of strafrecht aan te haken bij het criterium van de ernstige gedraging. Indien sprake is van een ernstige gedraging, dient de zaak strafrechtelijk te worden afgedaan en is geen rol weggelegd voor het bestuursrecht. ${ }^{86}$ Op het eerste gezicht lijkt dit een werkbaar criterium, maar er zijn onduidelijkheden aanwezig over dit criterium. Wanneer is immers sprake van een ernstige gedraging? Hoe dient te worden omgegaan met minder ernstige gedragingen? Dienen dergelijke delicten te worden overgeheveld naar het bestuursrecht? Naar mijn mening kan

81 Rogier 2014, p. 14.

82 J.A. Vervaele, 'Historische ontwikkeling van het bijzonder strafrecht', in: F.G.H. Kristen, R.M.I. Lamp, J.M.W. Lindeman \& M.J.J.P. Luchtman (red.), Bijzonder strafrecht. Strafrechtelijke handhaving van sociaal-economisch en fiscaal recht in Nederland, Den Haag: Boom Juridische uitgevers 2011, p. 25.

83 Ter vergelijking kan worden gewezen op het jaar 1975, toen in Duitsland de categorie van geringe overtredingen (Übertretungen) uit het Duitse Wetboek van Strafrecht werden geschrapt en veel van de overtredingen werden omgezet naar Ordnungswidrigkeiten. Deze Ordnungswidrigkeiten opgevat als bestuurlijke delicten - worden bedreigd met een Geldbusse (een bestuurlijke boete).

84 Kamerstukken II 2005/06, 29849, 30, p. 6.

85 Kamerstukken II 2005/06, 29849, 30, p. 6.

86 Rogier 2014, p. 32-33. 
worden beargumenteerd dat sprake is van een ernstige gedraging indien ten aanzien van die gedraging geen strafbeschikking kan worden uitgevaardigd. Het gevolg hiervan is dat gedragingen die wel middels een strafbeschikking kunnen worden afgedaan, zijn aan te merken als minder ernstige gedragingen, hetgeen zou betekenen dat zij mogelijkerwijze kunnen worden overgeheveld naar het bestuursrecht. Zeden- en geweldsmisdrijven die letsel tot gevolg hebben, komen in ieder geval niet in aanmerking voor afdoening door middel van een strafbeschikking, wat betekent dat deze misdrijven niet zouden kunnen worden overgeheveld naar het bestuursrecht. Het blijft echter een keuze van de wetgever welke delicten strafrechtelijk of bestuursrechtelijk dienen te worden afgedaan. 